\title{
Osteochondritis of tarsal/metatarsal bone
}

INSERM

\section{Source}

INSERM. (1999). Orphanet: an online rare disease and orphan drug data base.

Osteochondritis of tarsal/metatarsal bone. ORPHA:2054

Osteochondritis of tarsal/metatarsal bone is a very rare form of osteochondritis dissecans characterized by generally self-limiting bone lesions that may cause pain and swelling often localized at the tarsal navicular bone. 